\title{
Planktonic and benthic algae of a pampean river (Argentina) : comparative analysis 1
}

\author{
L.C. Solari ${ }^{2}$ \\ M.C. Claps ${ }^{2}$
}

Keywords : phytoplankton, phytobenthos, structure, dynamics, river, Argentina

In Buenos Aires province, the river Samborombón, which is typical of the plain, was sampled monthly during 1986-1987 in research carried out both on its physico-chemical characteristics and the communities present - plankton, phytobenthos, zoobenthos -. In this paper the structure and function of phytoplankton and benthic algal communities in the different sections of the river are compared. Both communities have definite limits as their components are not shared and show different strategies. Likewise, the environmental conditions along the river are variable, leading to differences in the planktonic and benthic algae at the locations studied.

Algues planctoniques et benthiques d'une rivière de plaine (Argentine) : étude comparative

Mots clés : phytoplancton, phytobenthos, structure, dynamique, rivière, Argentine

Dans la province de Buenos Aires, la rivière Samborombón, rivière typique de plaine, a été étudiée de mars 1986 à février 1987 dans le cadre d'une recherche relative aux caractéristiques physico-chimiques et aux communautés du plancton, du phytobenthos et du zoobenthos. Dans ce travail, la structure et la fonction du phytoplancton et du phytobenthos sont comparées dans diverses sections de la rivière. Les communautés ont des limites définies parce que leurs composantes sont différentes et montrent des stratégies contraires. Les caractéristiques du milieu sont variables tout au long de la rivière et déterminent des variations locales

\section{Introduction}

In Argentina, the algal communities in lotic bodies are poorly known. Research work on phytoplankton has been carried out mostly in the Paraná river (Bonetto et al. 1982, Anselmi de Manavella 1986, García de Emiliani 1981, 1985, 1988, 1990, García de Emiliani \& Anselmi de Manavella, 1983, Zalocar de Domitrovic \& Vallejos 1982). The algae associated to macrophytes and the epipelic algae were investigated by Claps $(1984,1987,1991,1992)$. In this paper the planktonic and epipelic algae in a plaine river of Buenos Aires province (Samborombón river) are studied. These algal communities showed differences in their

1. Scientific contribution $n^{\circ} 612$ of Institute of Limnology « $D^{r}$ Raúl A. Ringuelet".

2. Instituto de Limnología «D R.A. Ringuelet», av. Calchaquí km 23.5, 1888 Florencio Varela, Argentina. structure and dynamics in the different sections of the river, and also according to the seasons.

\section{Study Area}

The Samborombon river, with an approximate length of $140 \mathrm{~km}$, is placed in the so-called depressed Pampa, in Buenos Aires province (Frenguelli 1950). It is a typically plaine river, with very low gradient $(0,13 \mathrm{~m}$ $\mathrm{km}^{-1}$ ). Its flow is regulated by the rains regime. In summer it receives only the flow of underground waters.

Four sampling stations were established (every 30 $\mathrm{km}$, approximately) from its headwaters in Brandsen to its mouth in Río de la Plata estuary (Fig. 1), which show different characteristics (Table 1).

\section{Material and Methods}

Monthly samples were collected between March 1986 and February 1987 in four stations previously settled. For each sampling station the following va- 


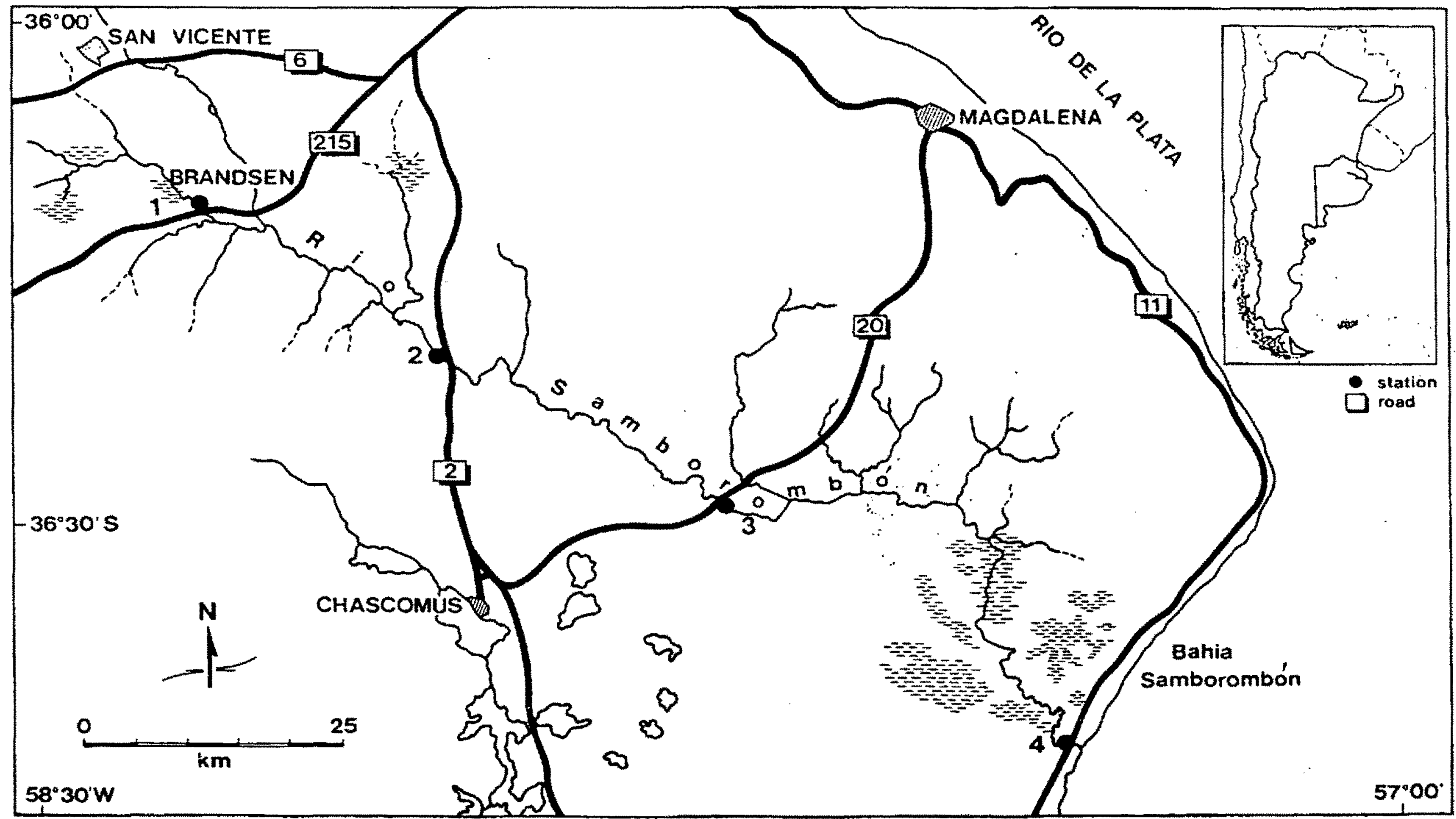

Fig. 1, Location of the sampling sites.

Fig. 1. Emplacement des 4 stations étudiées.

Table 1. Characteristics (mean values) of the sampling sectors from Samborombón river (standard deviation in brackets).

Tableau 1. Caractéristiques (valeurs moyennes) des stations étudiées de la rivière Samborombón (déviation standard entre parenthèses).

\begin{tabular}{|c|c|c|c|c|}
\hline & Station 1 & Station 2 & Station 3 & Station 4 \\
\hline Depth (m) & $0.5(16)$ & $0.6(17)$ & $1(0.2)$ & $2.15(0.2)$ \\
\hline Width (m) & & 12 & 20 & 16 \\
\hline Velocity $\left(\mathrm{m} \mathrm{sec}^{-1}\right)$ & $0.31(0.17)$ & $0.16(0.06)$ & $0.13(0.06)$ & $0.35(0.26)$ \\
\hline Transparency $(\mathrm{cm})$ & $22(7)$ & $22(8)$ & $27(8)$ & $10(3)$ \\
\hline Temperature $\left({ }^{\circ} \mathrm{C}\right)$ & $20(7)$ & $20(8)$ & $19(7)$ & $18(7)$ \\
\hline $\mathrm{pH}$ & $8.27(0.17)$ & $8.31(0.2)$ & $8.39(0.29)$ & $8.05(0.16)$ \\
\hline Conductivity $\left(\mu \mathrm{S} \mathrm{cm}^{-1}\right)$ & $3951(1789)$ & $3612(2006)$ & $4601(2381)$ & $5314(4088)$ \\
\hline Oxygen $\left(\mathrm{mg} \mathrm{l}^{-1}\right)$ & $8.17(2.2)$ & $8.31(1.6)$ & $7.61(2)$ & $7.38(1.7)$ \\
\hline $\mathrm{O}_{2}$ Saturation (\%) & $91(21)$ & $93(24)$ & $83(24)$ & $78(14)$ \\
\hline $\mathrm{SiO}_{2}\left(\mathrm{mg} \mathrm{l}^{-1}\right)$ & $21.8(5)$ & $20.8(4)$ & $17.95(4)$ & $18.02(4)$ \\
\hline C.O.D. (mg 1-1) & $27(7)$ & $25(7)$ & $23(8)$ & $23(6)$ \\
\hline $\mathrm{CO}_{3}=\left(\mathrm{mg} \mathrm{l}^{-1}\right)$ & $18(20)$ & $19(20)$ & $20(16)$ & $1(2)$ \\
\hline $\mathrm{HCO}_{3}^{-}\left(\mathrm{mg} \mathrm{l}^{-1}\right)$ & $468(87)$ & $345(103)$ & $326(86)$ & $311(65)$ \\
\hline $\mathrm{Cl}^{-}\left(\mathrm{mg} \mathrm{^{-1 } )}\right.$ & $1056(564)$ & $831(598)$ & $1134(826)$ & $1780(1914)$ \\
\hline $\mathrm{SO}_{4}=\left(\mathrm{mg} \mathrm{l}^{-1}\right)$ & $744(320)$ & $663(339)$ & $828(479)$ & $657(310)$ \\
\hline $\mathrm{K}^{+}\left(\mathrm{mg} \mathrm{1^{-1 }}\right)$ & $28(8)$ & $23(8)$ & $29(10)$ & $46(49)$ \\
\hline $\mathrm{Na}^{+}\left(\mathrm{mg} \mathrm{l}^{-1}\right)$ & $960(469)$ & $817(552)$ & $1018(550)$ & $1186(963)$ \\
\hline $\mathrm{Mg}^{++}\left(\mathrm{mg} \mathrm{l}^{-1}\right)$ & $111(72)$ & $100(69)$ & $124(92)$ & $160(168)$ \\
\hline Total Phosphorus (mg l-1) & $0.31(0.19)$ & $0.61(0.32)$ & $0.52(0.27)$ & $0.9(0.59)$ \\
\hline $\mathrm{PO}_{4}-\mathrm{P}\left(\mathrm{mg} \mathrm{l}^{-1}\right)$ & $0.037(0.027)$ & $0.278(0.19)$ & $0,182(0.2)$ & $0.147(0.1)$ \\
\hline $\mathrm{NO}_{2}-\mathrm{N}\left(\mathrm{mg} \mathrm{l}^{-1}\right)$ & $0.008(0.004)$ & $0.021(0.02)$ & $0.017(0.02)$ & $0.01(0.006)$ \\
\hline $\mathrm{NO}_{3}-\mathrm{N}(\mathrm{mg} \mathrm{l}-1)$ & $0.046(0.05)$ & $0.089(0.14)$ & $0.103(0.15)$ & $0.24(0.3)$ \\
\hline $\mathrm{NH}_{4}-\mathrm{N}\left(\mathrm{mg} \mathrm{l}^{-1}\right)$ & $0.16(0.13)$ & $0.23(0.34)$ & $0.31(0.38)$ & $0.097(0.07)$ \\
\hline
\end{tabular}


riables were recorded: water and sediment temperatures, transparency (Secchi disc), pH,conductivity, dissolved oxygen, principal ions and nutrients.

At each station from the littoral of the river, twenty five samples of undisturbed surface sediment were collected in plastic core barrels with an inner diameter of $12.5 \mathrm{~mm}$. Replicates were placed in individual jars and fixed with $5 \%$ formalin.

Samples of phytoplankton were taken from the center of the river with a 2 I Van Dorn bottle at $20-40 \mathrm{~cm}$ from the surface. They were fixed and preserved with Lugol's solution at $10 \%$.

The community's structure was analysed using the Shannon diversity index based on Information Theory (Legendre \& Legendre 1983).

\section{Results}

In the phytoplankton, 191 species were identified : 26 cyanophytes, 74 chlorophytes, 23 euglenophytes, 64 chrysophytes and 4 pyrrophytes (Solari, in press).

In the phytobenthos, 137 species were recorded : 12 cyanophytes, 28 chlorophytes, 12 euglenophytes and 85 chrysophytes (Claps, in press).

Estuarial and marine species were recorded : Actynoptychus sp., Navicula peregrina (Ehr.) Kütz., Surirella striatula Turp.and Thalassiosira lacustris (Grun.) Hasle in both plankton and benthos ; Biddulphia rhombus (Ehr.) W. Sm. and Dyctiocha fibula Ehr: only in the plankton and Caloneis permagma (J.W. Bail) Cl. only in the benthos.

The main phytoplankters were cyanophytes, chlorophytes and diatoms : Anabaena sphaerica Born. et Flah., Oscillatoria coerulescens Gicklhorn, Merismopedia tenuissima Lemm.,Gymnodininium sp, Monoraphidium contortum (Thuretin Breb.) Komarkova-Legnerova, M. minutum (Nag.) Komarkova-Legnerova, Scenedesmus quadricauda var. longispina (Chod.) G.M. Sm., S. bijuga (Turp.) Lagerh., S. falcatus Chodat, Crucigenia quadrata Morren, Hyaloraphidium arcuatum Kors., Korshikoviella limnetica (Lemm.) Silva, Pediastrum duplex Meyen, P. tetras (Ehr.) Ralfs, Cyclotella meneghiniana Kütz. and Nitzschia acicularis W. Sm.

The specific phytoplanktonic richness increased from the headwaters to stations 2 and 3. The largest number of species was recorded in summer. The minimun of species took place in autumn and winter. The maximal phytoplanktonic diversity occurred in summer and the minimal in autumn. The specific diversity decreased towards the mouth (Fig. 2). The algae increased their number in the medial parts of the river.
The phytoplankton pulses took place at the first 3 sampling stations in spring and in the mouth in autumn (Fig. 3).

In plankton, the cyanophytes were dominant at stations 1,2 and 4 ; whereas at station 3 the chlorophytes were also important (Fig. 4).

On the sediments, numerous species of diatoms and euglenophytes were present through all the sampling period : Pleurosira laevis (Ehr.) Compère and Surirella ovata Kütz. in headwaters ; Euglena acus Ehr., Amphora ovalis (Kütz.) Kütz.,Caloneis oregonica (Ehr.) Patr., Campylodiscus clypeus Ehr.,Gyrosigma terryanum (Perag.) Cl., Nitzschia sigma (Kütz.) W .Sm., Pleurosigma angulatum (Quek.) W. Sm., Pleurosira laevis, Surirella ovalis Breb. and S. ovata at station 3 ; Euglena gasterosteus Skuja, E. megalithus Skuja, E. acus, Caloneis oregonica, Navicula radiosa Kütz. and Surirella ovalis in the mouth.

The number of benthic species and specific diversity increased from the headwaters to the mouth. The highest values occurred in autumn and the lowest ones in summer (Fig. 2).

The highest benthic densities were found in the headwaters, decreasing towards the mouth (Fig. 3).

On the sediments, the pulses occurred in autumn in the headwaters and mouth, whereas in the median sections of the river they were observed in winter (Fig. 3).

On the sediments, the diatoms and cyanophytes were dominant in stations 1 and 3 ; in station 2 only the cyanophytes and in the mouth no dominant algal group was recorded (Fig. 4).

\section{Discussion}

In plankton, chloroccocales, centric and araphid diatoms, colonial and filamentous cyanophytes were dominant. On the sediments, other filamentous cyanophytes and diatoms with raphe were important.

Plankton was formed by typical species of free waters and on the sediments they were only found occasionally and in a very low number. Their presence, mostly at station 4 , was due to the action of the tide currents and to the waves, which cause their presence in coastal sediments.

In both communities the diatoms dominated alternatively. This behaviour could be due to the competition for silica. An accumulation of silica was observed in the water during summer, with minima of benthic and planktonic diatoms. This fact also observed in very different lotic bodies in the North Hemisphere, such as in the River Illinois (Wang \& Evans 1969) and in the River Nile (Mohamed et al. 1986). Besides, Melosira 

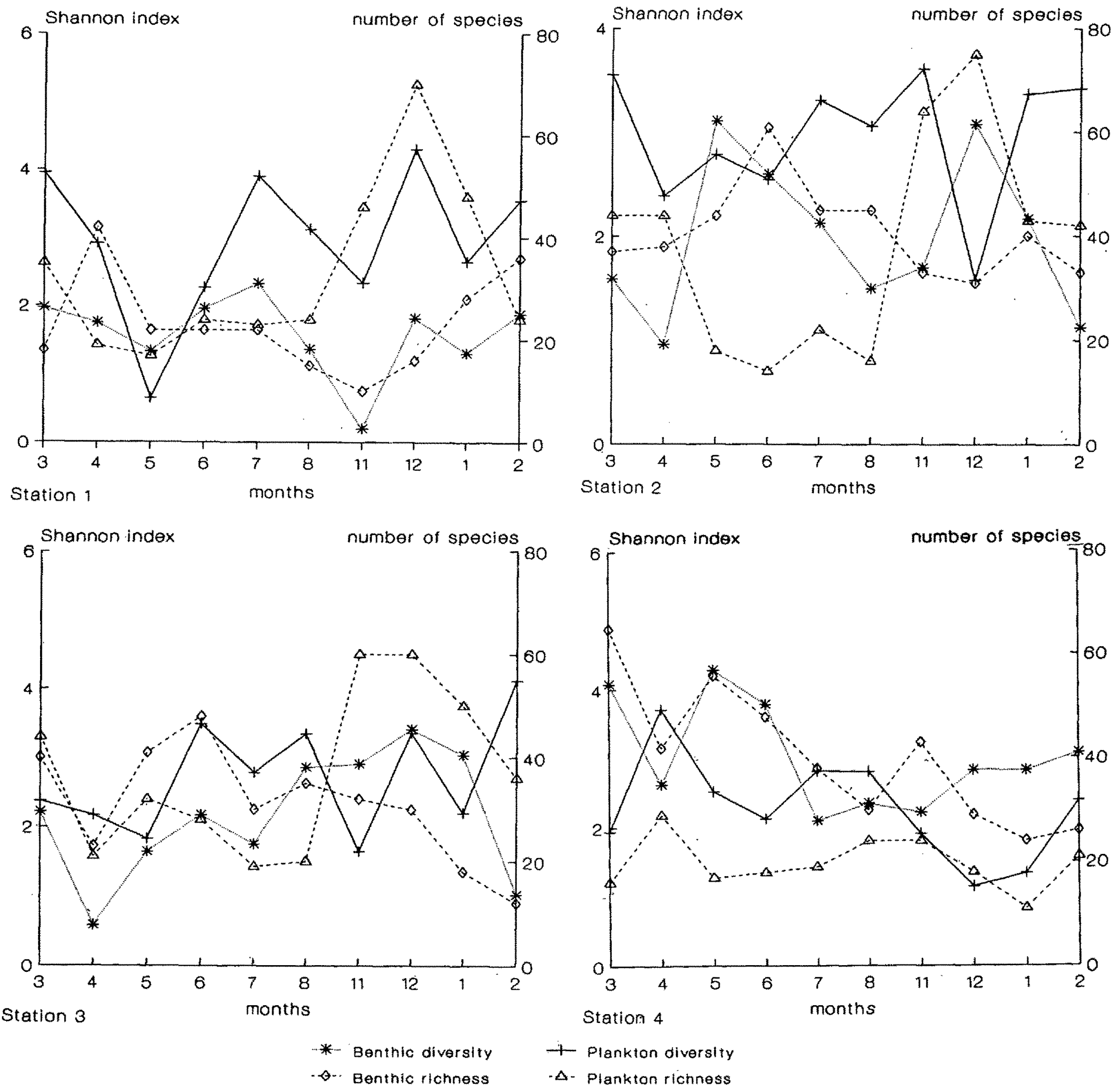

Fig. 2. Comparison of diversity (Shannon Index) and number of species between phytoplankton and benthic algae at four sampling sites of the Samborombón river

Fig. 2. Comparaison de la diversité (Indice de Shannon) et de la richesse spécifique du phytoplancton et des algues benthiques dans quatre stations de la rivière Samborombón. 

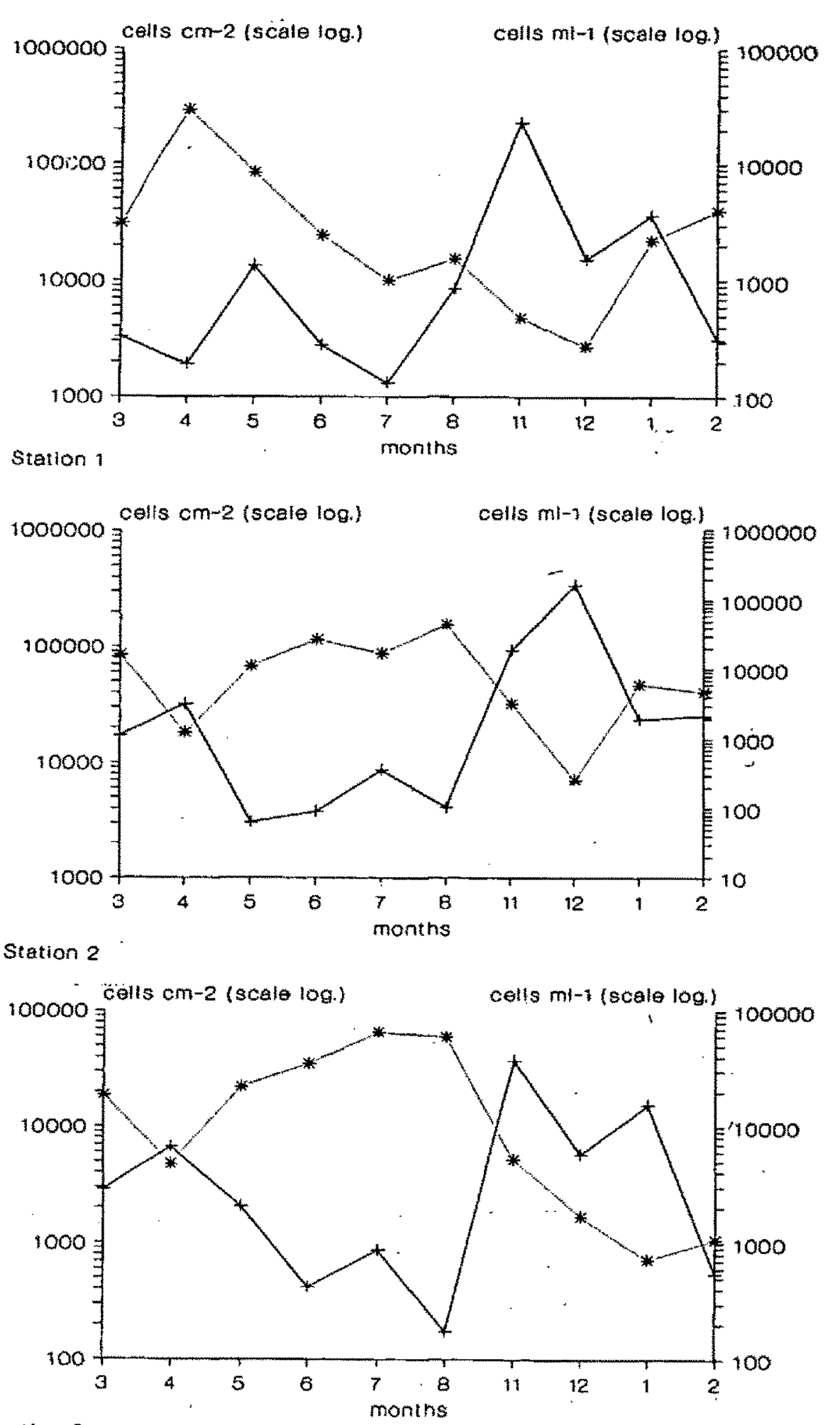

Station 3

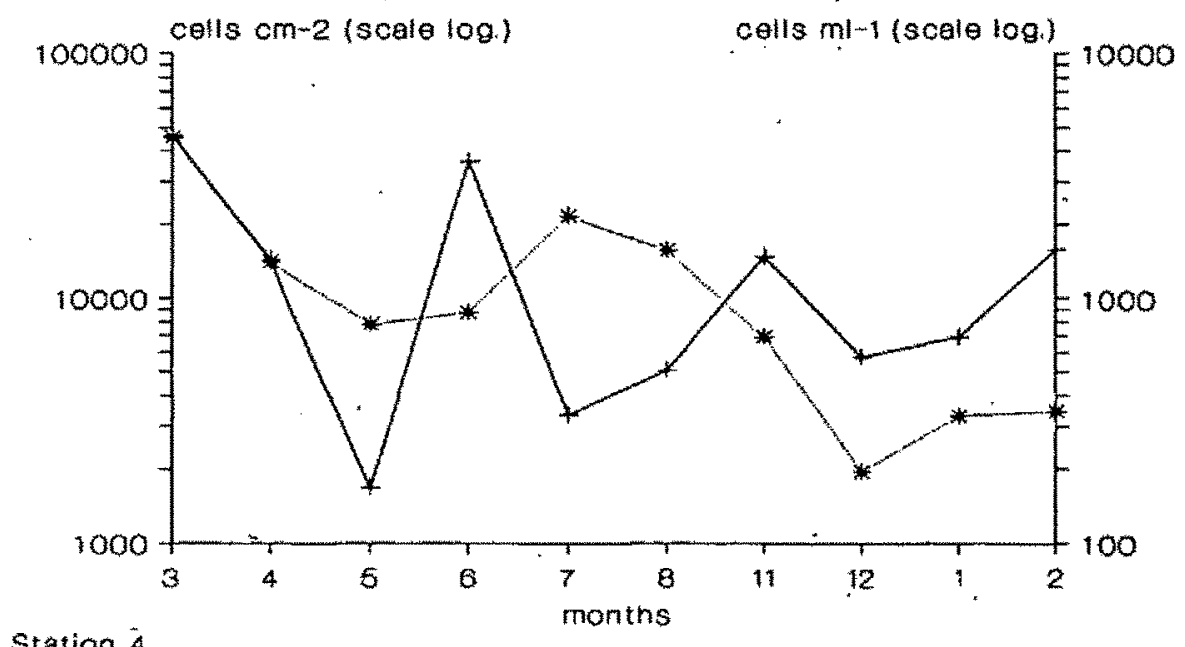

Station 4

*-Benthic algae - Phytoplankton

Fig. 3. Spatio-temporal changes of phytoplankton ( ${ }^{\circ}$ cells $\mathrm{ml}^{-1}$ ) and benthic algae $\left(\mathrm{n}^{\circ}\right.$ cells $\left.\mathrm{cm}^{-2}\right)$ in the Samborombon river.

Fig. 3. Variations spatio-temporelles du phytoplancton (nbre de cellules $\mathrm{ml}^{-1}$ ) et des algues benthiques (nbre de cellules $\mathrm{cm}^{-2}$ ) dans la rivière Samborombón. varians Ag., characteristic of the benthic community, showed peaks during autumn in plankton and in winter on the sediments.

The cyanophytes were dominant in both communities but with different constituents and they had through the year a similar number of species along the river. This similar condition in both communities is related to the large quantity of phosphates available in the river. The phytoplankton pulses were due to the cyanophytes whereas on the sediments the diatoms were also abundant.

Coinciding with what was pointed out by Round (1961) and Aykulu (1982), the peaks of cyanophytes and diatoms on the sediments took place simultaneously, whereas in plankton the cyanophytes maxima took place after those of the diatoms (Blum1956).

The chlorophytes constituted the most important group in number of species in plankton, whereas on the sediments they formed a scarce and poor in species group (Hutchinson 1975).

Although the euglenophytes had a number of species similar to that the cyanophytes, they did not show in both communities an outstanding role neither for their density nor for their presence in the annual cycle.

Agreeing with what was observed in the plankton by Aykulu (1978) in the River Avon, the algae increased their number in the median sections of the river.

The planktonic algae showed a positive correlation with temperature, which can be due to the fact that the importants species among cyanophytes and chlorophytes are considered thermophilic (Whitton 1975). The benthic algae showed an opposite behaviour as the summer conditions in littoral zone, with temperatures higher than the ones of the water and highlight densities, injure the algal metabolism. In winter, the weather conditions favoured their maximal growth.

In the phytoplankton, a temporal succession could be established, where the winter populations of diatoms were replaced by populations of chlorophytes and cyanophytes, as the water temperature in the river increased. On the sediments, on the contrary, a certain temporal homogeneity was found.

The great floods, which took place in September and October influenced in different ways both communities. The phytoplankton was enriched whereas on the sediments an impoverishment took place. In the plankton, the incorporation of species of lentic origin was observed, which caused the maximal peaks in this community. These algae came from lagoons, which are closed to the river and were found all along its course. On the contrary, on the sediments a reduction in their 


\section{Benthic algae}

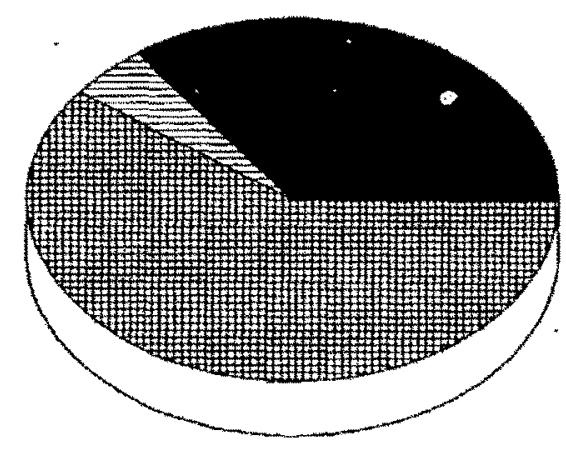

Station 1

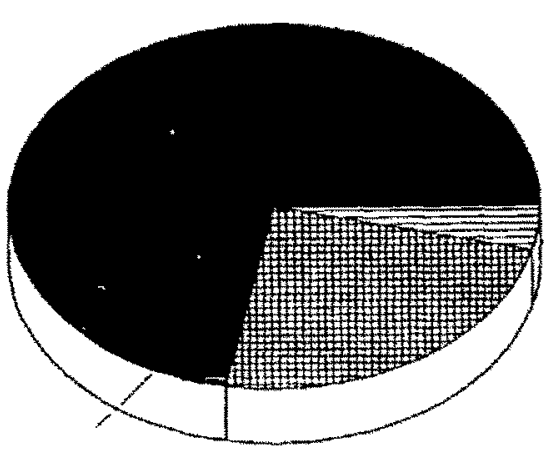

Station 2

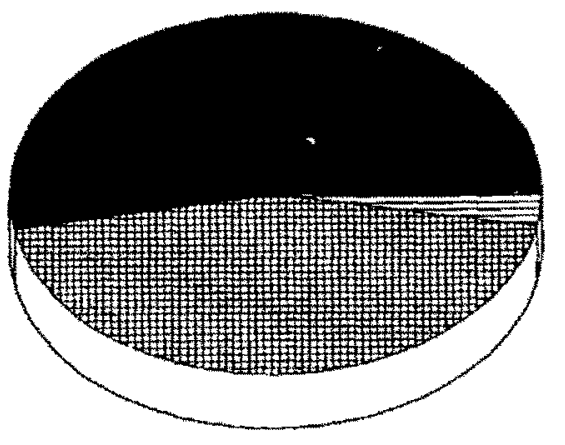

Station 3

Chromophytes

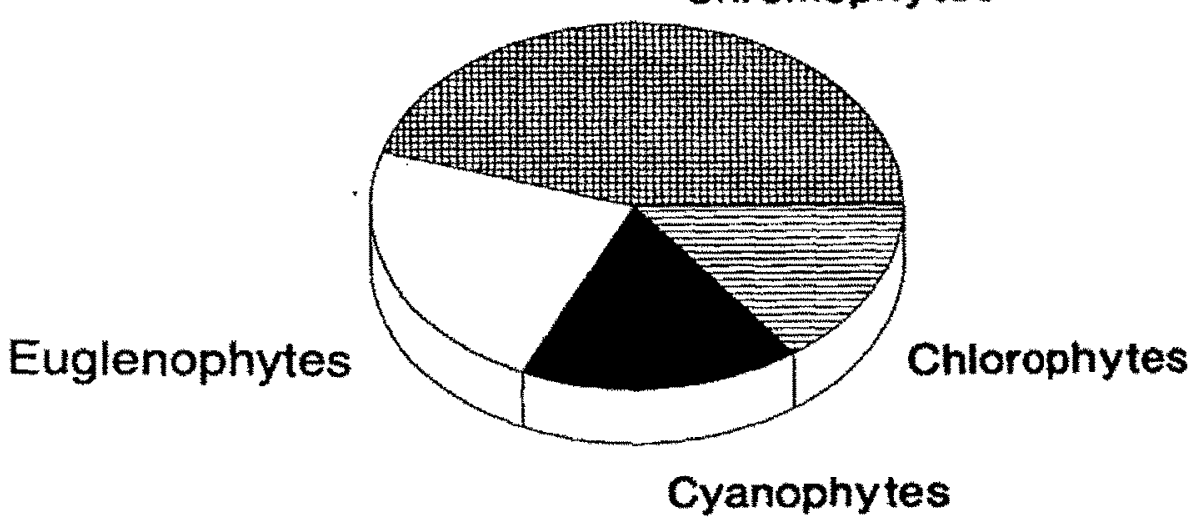

Station 4
Phytoplankton

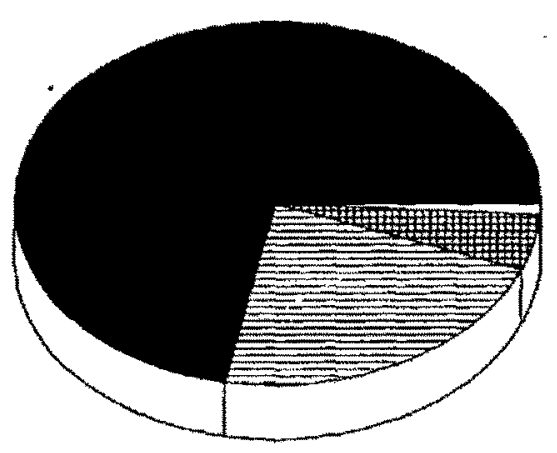

Station 1

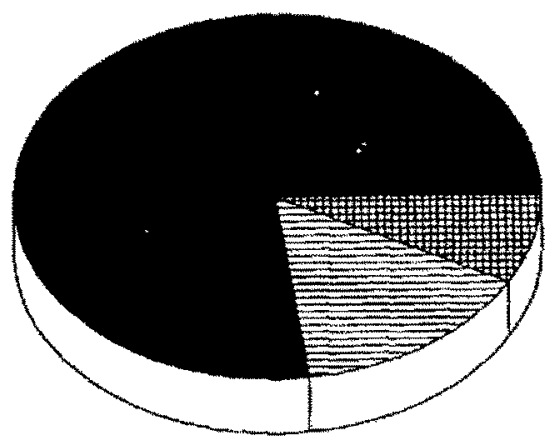

Station 2

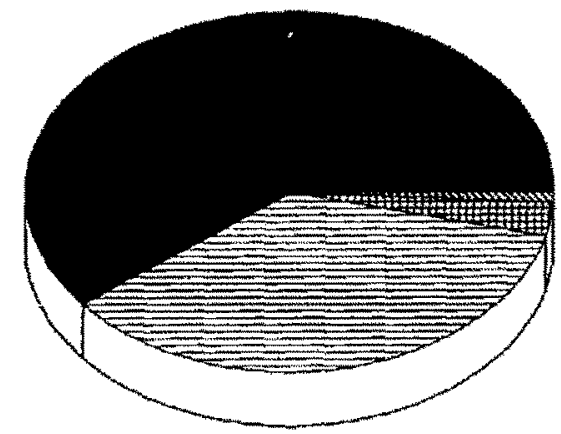

Station 3

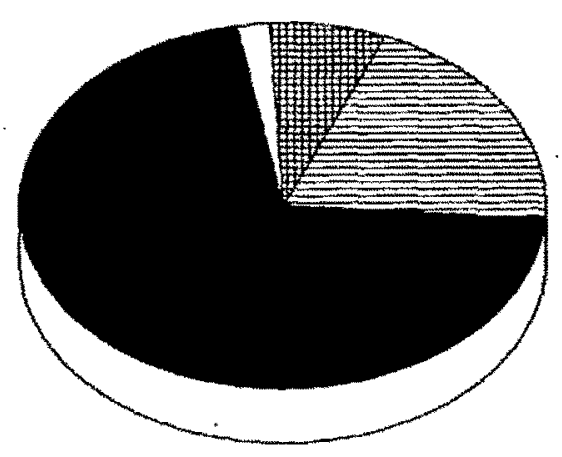

Station 4

Fig. 4. Composition (percentage) of phytoplankton and benthic algae at four sampling sites of Samborombón river. Fig. 4. Composition (pourcentage) du phytoplancton et des algues benthiques dans quatre stations de la rivière Samborombón. 
algal populations took place, which was even more evident in those sections of the river with slower speed (intermediate stations) in periods without floods.

Coinciding with what Wilderman (1987) pointed, it must be marked that in the area of influence of tides the community present on the sediments showed the greatest diversity, not so the plankton, which suffered a constant displacement with a loss of individuals due to the currents.

At last, it can be remarked that even though the scarce depth of the environment, which sometimes was not higher than $0.40 \mathrm{~m}$, both communities kept definite limits, with few species in common, non-simultaneous stational peaks, and a good development in the median sections of the river due to a greater availability of nutrients, slower speed of flow, greater transparence and a scarce variation in the level of the waters.

\section{Acknowledgements*}

This work was supported by the Consejo Nacional de Investigaciones Científicas y Técnicas (CONICET) (PID N N $^{\circ} 074100 / 85$ ).

\section{References}

Anselmi de Manavella M. 1986. - Estudios limnológicos en una sección transversal del tramo medio del río Paráá. XIV : fitoplancton. Rev. Asoc. Cienc. Nat. Litoral, $17: 183-201$.

Aykulu G. 1978. - A quantitative study of the phytoplankton of the river Avon, Bristol. Br. phycol.J., $13: 91-102$.

Aykulu G. 1982. - The epipelic algal flora of the river Avon. Br. phycol: $J, " 17: 27-38$

Blum J.L. 1956. - The ecology of river algae. Bot. Rev., $22: 291$ 341.

Bonetto A., Zalocar de Domitrovic Y. \& Vallejos E.R. 1982. Contribución al conocimiento del fitoplancton del Paraná Medio. I. Ecosur, $9: 189-212$

Claps M.C. 1984. - Perifiton en Scirpus californicus (Meyer) Steud. (Marjal de Ajó-Bahía Samborombón). Rev. Museo La Plata (N.S.), $13: 139-149$.

Claps M.C. 1987. - Valores de pigmentos hallados en el perifiton de Schoenoplectus californicus (Punta Atalaya-Río de la Plata). Limnobios., 2 : 653-656.

Claps M.C. 1991. - Diatom communities on aquatic macrophytes of pampasic lotic environments (Argentina). Acta Hydrobiol., $33: 195-208$.
Claps M.C. 1992. - Algas epipélicas del río Samborombón (prov. Buenos Aires). Biología Acuática, 15 : 234-235.

Claps M.C. - Structure and dynamics of epipelic algae from a plain river (río Samborombón, Argentina). Arch. Hydrobiol. (in press).

Frenguelli J. 1950. - Rasgos generales de la morfología y geología de la provincia de Buenos Aires. MOPBA, La Plata, 72 p.

García de Emiliani M.O. 1981. - Fitoplancton de los principales cauces y tributarios del valle aluvial del río Paraná : tramo GoyaDiamante. Rev. Asoc. Cienc. Nat. Litoral, $12: 112-125$.

García de Emiliani M.O. 1985. - Fitoplancton de los principales cauces y tributarios del valle aluvial del río Paraná : tramo Goya Diamante. II. Rev. Asoc. Cienc. Nat. Litoral, $16: 95-112$.

García de Emiliani M.O. 1988. - Fitoplancton y variables ambientales en cauces del Paraná Medio, Argentina : análisis de correlación canónica. Rev. Hydrobiol. Trop., 21 : 183-196.

García de Emiliani M.O. 1990. - Phytoplankton ecology of the Middle Paraná river. Acta Limnol. Brasil., 3 : 391-417.

García de Emiliani M.O. \& Anselmi de Manavella N. 1983:Fitoplancton de los principales cauces y tributarios del valle aluvial del río Paraná : tramo Goya-Diamante (II). Rev. Asoc. Cienc, Nat. Litoral, $14: 217-237$.

Hutchinson G.E. 1975. - A treatise on Limnology. Vol. III. John Wiley, Inc.,New York ; Chapman and Hall, Ltd., London : 660 p.

Hynes H.B.N. 1970. - The ecology of running waters. Univ. of Toronto Press : $555 \mathrm{p}$.

Legendre L. \& Legendre P. 1983. - Numerical Ecology. Elsevier Scientific Publishing Company, Amsterdam : 419 p.

Mohammed A.A., Ahmed A.M. \& Ahmed Z.A. 1986. - Studies on phytoplankton of the Nile System in upper Egypt. Limnologica, 17 : 99-117.

Round F.E. 1961. - Studies on bottom-living algae in some lakes of the English Lake District. Part V. The seasonal cycles of the Cyanophyceae. J. Ecol., $49: 31-38$.

Solari L.C. - Structure and dynamics of phytoplankton of Samborombón river (Buenos Aires, Argentina). Acta Hydrobiol. (in press).

Wang Ch.W. \& Evans R.L. 1969. - Variation of silica and diatoms in a stream. Limnol. Oceanogr, $14: 941-944$.

Whitton B.A. 1975. - Algae. In Whitton, B.A.(Ed.), River Ecology, Oxford : 81-105.

Wilderman C.C. 1987. - Patterns of distribution of diatom assemblages along environmental gradients in the Severn River Estuary, Chesapeake Bay, Maryland. J. Phycol., $23: 209-217$.

Zalocar de Domitrovic Y. \& Vallejos E.R. 1982. - Fitoplancton del río Alto Paraná. Variación estacional y distribución en relación a factores ambientales. Ecosur, $9: 1-28$. 